\title{
First human AIDS vaccine trial goes ahead without official OK
}

\section{London}

A CONTROVERSIAL trial of an AIDS (acquired immune deficiency syndrome) vaccine in Zaire has been given the full backing of the Zairean government in the face of mounting criticism that it is being carried out secretively and without the backing of the World Health Organisation.

The vaccine, which is the first to be tried in humans, has been developed by Dr Z. Lurhuma, director of the immunology laboratory of the University Clinic in Kinshasa, General J.-J. Salaun, head of the National Institute of Biomedical Research in Kinshasa (formerly the Pasteur Institute and now operated with French cooperative aid), and Dr Daniel Zagury of the Université Pierre et Marie Curie.

Zagury's research, much of which has been in cooperation with $\mathrm{Dr}$ Robert Gallo, has led him to design a vaccine aimed to trigger cells of the immune system to kill cells that are infected with the AIDS virus and carry viral envelope protein on their surface. Because the killing is mediated by cells of the immune system as well as by virus-neutralizing antibodies, the prototype vaccine has a different, but still undisclosed, basis from that of the several candidate vaccines that are based on purified envelope protein.

Animal tests followed by tests on a few uninfected human volunteers have been used to show that the vaccine is free of toxicological effects and can stimulate antibody production. As a result, the vaccine is now being tested on a small scale in volunteers at high risk in Zaire.

Zagury and his colleagues are not prepared to comment on the results of the trial so far, preferring to await its completion and formal presentation. They are, meanwhile, delighted by the statement of support and encouragement for the project from the Executive Council of Zaire that was published in Elima, the main Kinshasa newspaper, on 7 January. The statement looks forward to large-scale trials.

With a high incidence of AIDS and a correspondingly high risk of infection in Zaire, a large-scale trial of the vaccine should provide a trial of efficacy in a relatively short time. The rates and risks of infection in Zaire have been extensively documented as the result of an international project backed by the US Centers for Disease Control. But it seems clear that the project fell far short of the hopes of those in Zaire and that a vaccine trial is much more to the point. And they are disinclined to involve the World Health Organisation's Control Programme on AIDS headed by Dr Jonathan Mann, who until recently was deeply involved in the Centers for Disease Control project in Zaire.

\section{First Chinese scientist \\ London}

THERE is consternation among theoretical astrosphysicists in the West, and especially at Princeton, that Professor Fang $\mathrm{Li} \mathrm{Zhi}$ should have been one of the first casualties of the response of the government of China to the student demonstrations of recent weeks. The Chinese authorities announced last week that Professor Fang, who was vice-president of the Hefei University of Science and Technology in Anhui, was said to have been expelled from the Chinese Communist Party. Other reports said that Fang had been assigned to work at the observatory of the Chinese Academy of Sciences at Beijing.

Fang has been prominent among Chinese scientists collaborating with those overseas since the opening of China to the West a decade ago. For the first half of 1986, Fang worked at the Institute of Advanced Study at Princeton with the help of a fellowship under the scheme for scientific exchange between the United States and China which is administered by the US National Academy of Sciences.

Fang's colleagues at Princeton describe him as an able and imaginative scientist. Most recently, he appears to have been
NRC panel finds regulations on export too broad

\section{Washington}

ATtEMPTs in Congress to liberalize labyrinthine US export regulations are likely to be boosted by a controversial study made public last week by the National Research Council. The study, by a blue-ribbon panel chaired by Lew Allen Jr, former director of the National Security Agency and director of the Jet Propulsion Laboratory, supports the view common among high-technology industries that US

\section{IMAGE UNAVAILABLE FOR COPYRIGHT REASONS}

Lew Allen Jr - liberalizing regulations?

attempts to deny the Soviet bloc access to militarily important technology are overzealous. It concludes that the regulations - "not generally perceived as rational, credible and predictable" - encompass too many products and technologies to be administratively feasible, and estimates that US industry would gain about $\$ 9,000$ million per year in exports and 200,000 jobs if the United States adopted the same policies as its allies in the North Atlantic Treaty Organisation (NATO).

The United States is the only Western country that imposes unilateral controls on exports that are more stringent than those agreed jointly by member nations of CoCom, the informal Coordinating Committee on Multilateral Export Controls consisting of NATO members (except Iceland) and Japan.

In particular, US attempts to require overseas recipients of US technology to certify they will not re-export sensitive items have caused resentment among allied nations. The allies claim that such "extraterritorial" provisions violate international law. The Allen panel recommends that the United States restrict its controls to CoCom-proscribed items, and to those destined for a proscribed country or for one that has not agreed to abide by CoCom rules

Allen's critique is a slap in the face for Pentagon hardliners who have pressed for tighter export regulations. One such architect of defence policy, assistant secretary of defence Richard N. Perle, hit 